Discussion

\title{
Weighing the Benefits and Risks of Medical Marijuana Use: A Brief Review
}

\author{
Allison Karst \\ PGY2 Psychiatric Pharmacy Resident, Veterans Affairs Tennessee Valley Healthcare System, \\ Nashville, TN 37212, USA; allison.karst@va.gov; Tel.: +502-741-4979
}

Received: 2 November 2018; Accepted: 3 December 2018; Published: 6 December 2018

\begin{abstract}
Despite federal prohibition of medical marijuana possession, sale, and use, marijuana use continues to escalate as state legalization persists and expands. The purpose of this discussion is to provide a brief summary of the evidence regarding both potential benefits and risks of medical marijuana use.
\end{abstract}

Keywords: medical marijuana; marijuana; cannabis

Despite federal prohibition of medical marijuana possession, sale, and use, marijuana use continues to escalate as individual state legalization persists and expands (Table 1). As the medical marijuana landscape rapidly changes, it is imperative that healthcare providers stay up to date on available evidence regarding both the benefits and risks of use. Although it is important to note potential benefits demonstrated in specific disease states, evidence in most qualifying indications is insufficient, with the majority lacking randomized controlled trials (RCTs) (Table 2). 
Table 1. Qualifying indications by state [1].

\begin{tabular}{|c|c|c|c|c|c|c|c|c|c|c|c|c|c|c|c|c|c|c|c|c|c|c|c|c|c|c|c|c|c|c|c|}
\hline \multicolumn{32}{|c|}{ State [1] } \\
\hline Qualifying Conditions & AK & AR & $\mathrm{AZ}$ & CA & $\mathrm{CO}$ & CT & DC & $\mathrm{DE}$ & FL & $\mathrm{HI}$ & IL & MA & MD & $\mathrm{ME}$ & MI & MN & MO & MT & ND & $\mathrm{NH}$ & NJ & NM & NV & NY & $\mathrm{OH}$ & OR & PA & RI & UT & VT & WA \\
\hline Alzheimer's Disease & & $\mathrm{X}$ & $\mathrm{x}$ & & & & $\mathrm{X}$ & $\mathrm{X}$ & & & $x$ & & & $\mathrm{X}$ & $\mathrm{x}$ & & $\mathrm{X}$ & & $\mathrm{X}$ & $\mathrm{X}$ & & & & & $\mathrm{x}$ & $\mathrm{x}$ & & $x$ & $\mathrm{X}$ & & \\
\hline ALS (Lou Gehrig's Disease) & & $\mathrm{x}$ & $\mathrm{x}$ & & & $\mathrm{x}$ & $\mathrm{x}$ & $\mathrm{x}$ & $\mathrm{X}$ & & $\mathrm{x}$ & $x$ & & $x$ & $x$ & $\mathrm{x}$ & $\mathrm{x}$ & & $\mathrm{x}$ & $x$ & $\mathrm{x}$ & $\mathrm{x}$ & & $\mathrm{x}$ & $\mathrm{x}$ & & $\mathrm{x}$ & & $x$ & & \\
\hline Autism & & & & & & & $\mathrm{x}$ & & & & & & & & & & $\mathrm{x}$ & & & & & & & & & & $\mathrm{x}$ & & $\mathrm{x}$ & & \\
\hline Arthritis & & $x$ & & $\mathrm{x}$ & & & $\mathrm{x}$ & & & & & & & & & & & & & & & $\mathrm{x}$ & & & & & & & & & \\
\hline Cachexia (or Anorexia) & $\mathrm{x}$ & $\mathrm{x}$ & $\mathrm{X}$ & $\mathrm{x}$ & $x$ & $\mathrm{X}$ & $\mathrm{x}$ & $\mathrm{x}$ & & $\mathrm{x}$ & $\mathrm{x}$ & & $\mathrm{x}$ & $\mathrm{X}$ & $\mathrm{x}$ & $\mathrm{x}$ & $\mathrm{x}$ & $\mathrm{x}$ & $\mathrm{x}$ & $\mathrm{x}$ & & $\mathrm{x}$ & $\mathrm{X}$ & & & $\mathrm{x}$ & & $\mathrm{X}$ & $\mathrm{x}$ & $\mathrm{x}$ & $\mathrm{x}$ \\
\hline Cancer & $\mathrm{x}$ & $x$ & $\mathrm{x}$ & $\mathrm{x}$ & $x$ & $\mathrm{x}$ & $\mathrm{x}$ & $\mathrm{x}$ & $x$ & $\mathrm{x}$ & $\mathrm{x}$ & $\mathrm{x}$ & & $x$ & $\mathrm{x}$ & $\mathrm{x}$ & $\mathrm{x}$ & $\mathrm{x}$ & $\mathrm{x}$ & $\mathrm{x}$ & $\mathrm{x}$ & $\mathrm{x}$ & $\mathrm{x}$ & $\mathrm{x}$ & $\mathrm{x}$ & $\mathrm{x}$ & $\mathrm{x}$ & $\mathrm{x}$ & $\mathrm{x}$ & $\mathrm{x}$ & $\mathrm{x}$ \\
\hline Cerebral palsy & & & & & & $\mathrm{X}$ & $\mathrm{x}$ & & & & & & & & & & & & & & & & & & & & & & & & \\
\hline $\begin{array}{l}\text { Chronic or Debilitating } \\
\text { Disease }\end{array}$ & & $x$ & & & & $\mathrm{x}$ & $\mathrm{x}$ & & & & $x$ & & & $x$ & & & $\mathrm{x}$ & & $\mathrm{x}$ & $\mathrm{x}$ & $x$ & $x$ & & $\mathrm{x}$ & & & $\mathrm{x}$ & & & & \\
\hline Chronic pain & $\mathrm{x}$ & $\mathrm{x}$ & $\mathrm{X}$ & $\mathrm{x}$ & $\mathrm{x}$ & $\mathrm{X}$ & $\mathrm{x}$ & $\mathrm{X}$ & $x$ & $\mathrm{x}$ & $\mathrm{x}$ & & $\mathrm{x}$ & $\mathrm{x}$ & $\mathrm{X}$ & $\mathrm{x}$ & $\mathrm{x}$ & $\mathrm{X}$ & $\mathrm{x}$ & $\mathrm{x}$ & & $\mathrm{x}$ & $\mathrm{X}$ & $\mathrm{X}$ & $\mathrm{X}$ & $\mathrm{x}$ & $\mathrm{x}$ & $\mathrm{X}$ & $\mathrm{X}$ & $\mathrm{X}$ & $\mathrm{X}$ \\
\hline Crohn's Disease & & $x$ & $\mathrm{X}$ & & & $\mathrm{x}$ & $\mathrm{x}$ & & $\mathrm{X}$ & $\mathrm{x}$ & & $\mathrm{X}$ & & $x$ & $x$ & $x$ & $x$ & $x$ & $\mathrm{x}$ & $\mathrm{x}$ & & $\mathrm{x}$ & & & $x$ & & $x$ & $x$ & $x$ & $x$ & $x$ \\
\hline Cystic Fibrosis & & & & & & $\mathrm{X}$ & $\mathrm{x}$ & & & & & & & & & & & & & & & & & & & & & & & & \\
\hline Fibromyalgia & & $x$ & & & $x$ & & $\mathrm{x}$ & & & & $\mathrm{x}$ & & & & & & & & $\mathrm{x}$ & & & & & & $\mathrm{X}$ & & & & & & \\
\hline Glaucoma & $\mathrm{x}$ & $\mathrm{X}$ & $\mathrm{X}$ & $\mathrm{x}$ & $\mathrm{X}$ & $\mathrm{x}$ & $\mathrm{x}$ & & $\mathrm{X}$ & $\mathrm{X}$ & $\mathrm{x}$ & $\mathrm{x}$ & & $x$ & $\mathrm{x}$ & $\mathrm{x}$ & $\mathrm{x}$ & $\mathrm{x}$ & $\mathrm{x}$ & $\mathrm{x}$ & $x$ & $\mathrm{x}$ & $\mathrm{x}$ & & $\mathrm{x}$ & $\mathrm{x}$ & $\mathrm{X}$ & $\mathrm{X}$ & & $\mathrm{x}$ & $\mathrm{x}$ \\
\hline Hepatitis C & & $\mathrm{x}$ & $\mathrm{X}$ & & & & $\mathrm{x}$ & & & & $\mathrm{x}$ & $\mathrm{X}$ & & $x$ & $\mathrm{x}$ & & $\mathrm{x}$ & & $\mathrm{x}$ & $\mathrm{x}$ & & $\mathrm{x}$ & & & $\mathrm{x}$ & & & $\mathrm{X}$ & & & $\mathrm{x}$ \\
\hline HIV/AIDS & $\mathrm{x}$ & $\mathrm{x}$ & $\mathrm{X}$ & $x$ & $\mathrm{x}$ & $\mathrm{X}$ & $\mathrm{x}$ & $\mathrm{x}$ & $\mathrm{X}$ & $\mathrm{x}$ & $\mathrm{x}$ & $\mathrm{X}$ & & $\mathrm{x}$ & $\mathrm{X}$ & $\mathrm{x}$ & $\mathrm{x}$ & $\mathrm{X}$ & $\mathrm{x}$ & $\mathrm{x}$ & $\mathrm{X}$ & $\mathrm{x}$ & $\mathrm{x}$ & $\mathrm{X}$ & & $\mathrm{x}$ & $\mathrm{X}$ & $\mathrm{X}$ & $x$ & $\mathrm{X}$ & $\mathrm{x}$ \\
\hline Migraine & & & & $\mathrm{x}$ & & & $\mathrm{x}$ & & & & & & & & & & $\mathrm{x}$ & & & & & & & & & & & & & & \\
\hline Multiple Sclerosis & $x$ & $\mathrm{X}$ & & & & $x$ & $\mathrm{x}$ & & $\mathrm{x}$ & $\mathrm{x}$ & $\mathrm{x}$ & $\mathrm{X}$ & & $\mathrm{x}$ & & & $\mathrm{x}$ & & $\mathrm{x}$ & $\mathrm{x}$ & $\mathrm{x}$ & $\mathrm{x}$ & & $\mathrm{x}$ & $\mathrm{x}$ & & $\mathrm{x}$ & & $\mathrm{X}$ & $\mathrm{x}$ & \\
\hline Nausea & $\mathrm{x}$ & $\mathrm{x}$ & $\mathrm{X}$ & $\mathrm{x}$ & $\mathrm{x}$ & & $\mathrm{x}$ & $\mathrm{x}$ & & $\mathrm{x}$ & $\mathrm{x}$ & & $\mathrm{x}$ & $\mathrm{x}$ & $\mathrm{x}$ & & & $\mathrm{x}$ & $\mathrm{x}$ & $\mathrm{x}$ & & $\mathrm{x}$ & $\mathrm{x}$ & & & $\mathrm{x}$ & & $\mathrm{X}$ & & $\mathrm{x}$ & $\mathrm{X}$ \\
\hline Parkinson's Disease & & & & & & $\mathrm{x}$ & $\mathrm{x}$ & & $x$ & & $\mathrm{x}$ & $\mathrm{x}$ & & $\mathrm{x}$ & & & $\mathrm{x}$ & & & $\mathrm{x}$ & & $\mathrm{x}$ & & $\mathrm{x}$ & $\mathrm{x}$ & & $\mathrm{x}$ & & & $\mathrm{x}$ & \\
\hline Persistent Muscle Spasms & & $\mathrm{x}$ & $\mathrm{x}$ & $\mathrm{x}$ & $\mathrm{x}$ & $\mathrm{x}$ & $\mathrm{x}$ & $\mathrm{x}$ & $\mathrm{x}$ & $\mathrm{x}$ & & & $\mathrm{x}$ & & $\mathrm{x}$ & $\mathrm{x}$ & $\mathrm{x}$ & $\mathrm{x}$ & $\mathrm{x}$ & $\mathrm{x}$ & $x$ & & $\mathrm{x}$ & & & $x$ & $\mathrm{x}$ & $\mathrm{x}$ & $\mathrm{x}$ & & $x$ \\
\hline Peripheral neuropathy & & $\mathrm{X}$ & & & $\mathrm{X}$ & & $\mathrm{x}$ & & & & $\mathrm{x}$ & & & & & & $\mathrm{x}$ & & & & & $\mathrm{x}$ & & $\mathrm{x}$ & & & $\mathrm{X}$ & & & & \\
\hline Psoriasis & & & & & & $\mathrm{X}$ & $\mathrm{x}$ & & & & & & & & & & & & & & & & & & & & & & & & \\
\hline PTSD & & $\mathrm{X}$ & $\mathrm{X}$ & & $\mathrm{X}$ & $\mathrm{X}$ & $\mathrm{x}$ & $\mathrm{x}$ & $\mathrm{X}$ & $\mathrm{X}$ & $\mathrm{x}$ & & & $\mathrm{X}$ & $\mathrm{x}$ & $\mathrm{X}$ & $\mathrm{x}$ & & $\mathrm{x}$ & $\mathrm{x}$ & $\mathrm{x}$ & $\mathrm{x}$ & $\mathrm{X}$ & & $\mathrm{x}$ & $\mathrm{x}$ & $x$ & $\mathrm{X}$ & $x$ & $\mathrm{x}$ & $\mathrm{X}$ \\
\hline Seizures (or Epilepsy) & $\mathrm{x}$ & $x$ & $x$ & $\mathrm{x}$ & $\mathrm{x}$ & $\mathrm{X}$ & $\mathrm{x}$ & $\mathrm{x}$ & $\mathrm{X}$ & $\mathrm{x}$ & $\mathrm{x}$ & & $\mathrm{x}$ & $\mathrm{x}$ & $\mathrm{x}$ & $\mathrm{x}$ & $\mathrm{x}$ & $x$ & $\mathrm{x}$ & $\mathrm{x}$ & $\mathrm{x}$ & $\mathrm{x}$ & $\mathrm{x}$ & $\mathrm{x}$ & $\mathrm{x}$ & $\mathrm{x}$ & $x$ & $\mathrm{x}$ & $\mathrm{x}$ & $\mathrm{x}$ & $x$ \\
\hline Terminal IIlness & & & & & & & $\mathrm{x}$ & $x$ & $x$ & & & & & & & $\mathrm{x}$ & $\mathrm{x}$ & & & & $\mathrm{X}$ & $\mathrm{x}$ & & & & & $\mathrm{x}$ & & & $\mathrm{x}$ & $\mathrm{x}$ \\
\hline Tourette's syndrome & & $\mathrm{X}$ & & & & & $\mathrm{x}$ & & & & $\mathrm{X}$ & & & & & & $\mathrm{x}$ & & & & & & & & $\mathrm{X}$ & & & & & & \\
\hline Ulcerative Colitis & & $\mathrm{x}$ & & & & $\mathrm{x}$ & $\mathrm{x}$ & & & & & & & $\mathrm{x}$ & & & & & & & & & & & $\mathrm{x}$ & & & & & & \\
\hline
\end{tabular}


Table 2. Potential benefits of marijuana [1-33].

\begin{tabular}{|c|c|}
\hline Qualifying Condition & Summary/Quality of Evidence \\
\hline Amyotrophic Lateral Sclerosis (ALS) $[2,3]$ & Insufficient evidence; Single RCT showed no significant difference on primary or secondary outcomes \\
\hline Alzheimer's Disease $[2,4-9]$ & $\begin{array}{l}\text { No published RCTs. Cochrane systematic review concluded that there is insufficient evidence that oral cannabinoids are effective for the } \\
\text { treatment of behavioral disturbances associated with dementia. There is limited evidence that oral cannabinoids are ineffective. }\end{array}$ \\
\hline Autism [10] & Data limited to animal model-based research, small case series or single case reports \\
\hline Arthritis [11] & While there is moderate evidence in chronic pain, there is insufficient evidence in arthritic conditions \\
\hline Cachexia/Anorexia [2,11-15] & U.S. Food and Drug Administration (FDA)-approved product available (dronabinol); low-quality evidence \\
\hline Cancer [16] & RCTs only in supportive care measures; preliminary evidence of anti-proliferative properties indicates an area of future research \\
\hline Cerebral Palsy [2] & $\begin{array}{l}\text { Low to moderate evidence for symptoms of cerebral palsy, such as pain, spasms, and seizures; however, there is insufficient evidence in } \\
\text { this specific population for recommendations }\end{array}$ \\
\hline Chronic Pain $[2,11,17,18]$ & Substantial evidence for benefit with cannabis; moderate evidence for benefit with nabiximols \\
\hline Crohn's Disease [19,20] & Insufficient and inconclusive evidence \\
\hline Cystic Fibrosis [2] & Preliminary evidence only; No RCTs; insufficient evidence \\
\hline Fibromyalgia $[21,22]$ & Cohort studies only, no RCTs for pain in fibromyalgia; moderate evidence in sleep improvement \\
\hline Glaucoma $[2,23-27]$ & $\begin{array}{l}\text { Significantly lowers intraocular pressure (IOP) for } 4 \text { hours; Insufficient evidence to indicate that marijuana is safer or more effective than } \\
\text { existing pharmacotherapy or surgery for reduction of IOP }\end{array}$ \\
\hline Hepatitis C [2] & No RCTs; insufficient evidence \\
\hline $\begin{array}{l}\text { Human Immunodeficiency Virus (HIV)/Acquired } \\
\text { Immunodeficiency Syndrome (AIDS) [28-31] }\end{array}$ & $\begin{array}{l}\text { Moderate evidence for FDA-approved product (dronabinol); Low-quality evidence suggesting that cannabinoids and marijuana are } \\
\text { associated with weight gain in patients with HIV/AIDS }\end{array}$ \\
\hline Migraine [32] & Retrospective chart review demonstrated decreased frequency of migraines; No RCTs; insufficient evidence \\
\hline Multiple Sclerosis (MS) or Persistent Muscle Spasms [2,33-36] & Moderate quality evidence to suggest benefit \\
\hline Nausea $[2,17,37]$ & FDA-approved products available (nabilone, dronabinol); Low quality evidence for benefit with marijuana \\
\hline Parkinson's Disease [38-40] & $\begin{array}{l}\text { Results of trials studying the use of oral cannabinoids in Parkinson's Disease have been controversial and inconclusive. Most } \\
\text { importantly, there have been no RCTs examining marijuana specifically in this population. }\end{array}$ \\
\hline Peripheral Neuropathy $[2,11,18]$ & Moderate to substantial evidence to suggest benefit of cannabinoids in peripheral neuropathy \\
\hline Psoriasis [2] & No RCTs; insufficient evidence \\
\hline Post-Traumatic Stress Disorder (PTSD) [41-44] & Insufficient evidence; potential harm \\
\hline Seizures [45-47] & Moderate-quality evidence for use of cannabidiol (CBD) (but not marijuana) as adjunctive therapy in patients with refractory seizures \\
\hline Tourette's Syndrome [10] & $\begin{array}{l}\text { Limited evidence that } \Delta \text {-9-tetrahydrocannabinol (THC) capsules are an effective treatment for improving symptoms of Tourette } \\
\text { syndrome }\end{array}$ \\
\hline Ulcerative Colitis [2] & No RCTs; insufficient evidence \\
\hline
\end{tabular}


Marijuana and oral cannabinoids (dronabinol, nabilone, oral THC) have been associated with adverse effects, including serious adverse effects as well as study withdrawal. The most commonly reported adverse effects include asthenia, balance problems, disorientation, gastrointestinal effects, euphoria, somnolence, dry mouth, fatigue, hallucinations, paranoia, and agitation [11,17].

Marijuana use has a negative effect on mental health and neurologic function. Marijuana users are at risk for tolerance, dependence, and withdrawal [4,18,44]. Multiple studies have examined the negative effects of marijuana on acute and long-term cognition, including impairment in attention, impulse control, decision-making processes, working memory, and executive function. Additionally, marijuana has been associated with an early onset of psychotic disorders, an exacerbated course of illness in established psychotic disorders, exacerbation of mania in bipolar disorders, and worsened symptoms of PTSD [4,11,18,41,44].

Pulmonary, cardiovascular, and carcinogenic effects of marijuana remain controversial $[4,44,48,49]$. In vivo and in vitro studies have demonstrated that marijuana inhibits several hepatic enzymes (CYP2D6, CYP2C19, CYP2C9, CYP3A4), and preliminary evidence in humans suggests that marijuana may interact with serum drug concentrations of warfarin and antiretroviral therapies [16,50-52]. However, additional research is warranted in these areas as the risk of clinically significant drug interactions is unknown [53].

When discussing medical marijuana use, pharmacists must be knowledgeable about potential benefits and risks. Disease states with substantial evidence include chronic pain, chemotherapy-induced nausea and vomiting (oral cannabinoids only), and patient-reported spasticity in MS [2]. Further research is warranted, particularly regarding products similar to those currently available in dispensaries. Because medical marijuana lacks quality standards and FDA regulation, available products have shown significant inconsistencies, with one study revealing that only $17 \%$ of edible cannabis products were accurately labeled [54]. It is the responsibility of prescribers and pharmacists to educate patients on potential adverse events and drug interactions. Other pertinent issues to consider are marijuana dosing as well as the inability to extrapolate evidence between oral cannabinoids and marijuana due to differences in chemical composition. As a result of limited high-quality evidence and lack of regulation, the potential benefits and risks must be weighed carefully to make appropriate clinical decisions.

Funding: This research received no external funding.

Conflicts of Interest: The author has no potential conflict of interest or financial disclosures to report.

\section{References}

1. State Medical Marijuana Laws. National Conference of State Legislatures Website. Available online: http: / / www.ncsl.org/research/health/state-medical-marijuana-laws.aspx (accessed on 26 November 2018).

2. The National Academies of Sciences, Engineering, and Medicine. The Health Effects of Cannabis and Cannabinoids: The Current State of Evidence and Recommendations for Research; The National Academies Press: Washington, DC, USA, 2017. Available online: https:/ /www.nap.edu/catalog/24625/the-healtheffects-of-cannabis-and-cannabinoids-the-current-state (accessed on 11 November 2018).

3. Weber, M.; Goldman, B.; Truniger, S. Tetrahydrocannabinol (THC) for cramps in amyotrophic lateral sclerosis: A randomized, double-blind crossover trial. J. Neurol. Neurosurg. Psychiatry 2010, 81, 1135-1140. [CrossRef] [PubMed]

4. Wilkinson, S.T.; Yarnell, S.; Radhakrishnan, R.; Ball, S.A.; D'Souza, D.C. Marijuana legalization: Impact on physicians and public health. Annu. Rev. Med. 2016, 67, 453-466. [CrossRef] [PubMed]

5. Wilkinson, S.T.; Stefanovics, E.; Rosenheck, R.A. Marijuana use is associated with worse outcomes in symptom severity and violent behavior in patients with post-traumatic stress disorder. J. Clin. Psychiatry 2015, 76, 1174-1180. [CrossRef] [PubMed]

6. Krishnan, S.; Cairns, R.; Howard, R. Cannabinoids for the treatment of dementia. Cochrane Database Syst. Rev. 2009, 2. [CrossRef] 
7. Volicer, L.; Stelly, M.; Morris, J.; McLaughlin, J.; Volicer, B.J. Effects of Dronabinol on anorexia and disturbed behavior in patients with Alzheimer's disease. Int. J. Geriatr. Psychiatry 1997, 12, 913-919. [CrossRef]

8. van den Elsen, G.A.; Ahmed, A.I.; Verkes, R.-J.; Feuth, T.; van der Marck, M.A.; Olde Rikkert, M.G. Effects of tetrahydrocannabinol on balance and gait in patients with dementia: A randomized controlled crossover trial. Am. J. Geriatr. Psychiatry 2015, 23, 1214-1224. [CrossRef]

9. Walther, S.; Mahlberg, R.; Eichmann, U.; Kunz, D. Delta-9-tetrahydrocannabinol for nighttime agitation in severe dementia. Psychopharmacology (Berl.) 2006, 185, 524-528. [CrossRef]

10. Hadland, S.E.; Knight, J.R.; Harris, S.K. Medical marijuana: Review of the science and implications for developmental-behavioral pediatric practice. J. Dev. Behav. Prediatr. 2015, 36, 115-123. [CrossRef]

11. Nugent, S.M.; Morasco, B.J.; O’Neil, M.E.; Freeman, M.; Low, A.; Kondo, K.; Elven, C.; Zakher, B.; Motu'apuaka, M.; Paynter, R.; et al. The effects of cannabis among adults with chronic pain and an overview of general harms. Ann. Intern. Med. 2017, 167, 319-332. [CrossRef]

12. Strasser, F.; Luftner, D.; Possinger, K.; Ernst, G.; Ruhstaller, T.; Meissner, W.; Ko, Y.D.; Schnelle, M.; Reif, M.; Cerny, T.; et al. Comparison of orally administered cannabis extra and delta-9-tetrahydrocannabinol in treating patients with cancer-related anorexia-cachexia syndrome: A multicenter phase III, randomized, double-blind placebo-controlled clinical trial from the Cannabis-In-Cachexia-Study-Group. J. Clin. Oncol. 2006, 24, 3394-3400.

13. Foltin, R.W.; Fischman, M.W.; Byrne, M.F. Effects of smoked marijuana on food intake and body weight of humans living in a residential laboratory. Appetite 1988, 11,1-14. [CrossRef]

14. Haney, M.; Gunderson, E.W.; Rabkin, J.; Hart, C.L.; Vosburg, S.K.; Comer, S.D.; Foltin, R.W. Dronabinol and marijuana in HIV-positive marijuana smokers: Caloric intake, mood, and sleep. J. Acquir. Immune Defic. Syndr. 2007, 45, 545-554. [CrossRef] [PubMed]

15. Jatoi, A.; Windschitl, H.E.; Loprinzi, C.L.; Sloan, J.A.; Dakhil, S.R.; Mailliard, J.A.; Pundaleeka, S.; Kardinal, C.G.; Fitch, T.R.; Krook, J.E.; et al. Dronabinol versus megestrol acetate versus combination therapy for cancer-associated anorexia: A North Central Cancer Treatment Group Study. J. Clin. Oncol. 2002, 20, 567-573. [CrossRef] [PubMed]

16. Birdsall, S.M.; Birdsall, T.C.; Tims, L.A. The use of medical marijuana in cancer. Curr. Oncol. Rep. 2016, 18, 40. [CrossRef] [PubMed]

17. Whiting, P.F.; Wolff, R.F.; Deshpande, S.; Di Nisio, M.; Duffy, S.; Hernandez, A.V. Cannabinoids for medical use: A systematic review and meta-analysis. JAMA 2015, 313, 2456-2473. [CrossRef] [PubMed]

18. Andrade, M.H.; Carter, G.M.; Shaparin, N.; Suslov, K.; Ellis, R.J.; Ware, M.A.; Abrams, D.I.; Prasad, H.; Wilsey, B.; Indyk, D.; et al. Inhaled cannabis for chronic neuropathic pain: A meta-analysis of individual patient data. J. Pain 2015, 16, 1221-1232. [CrossRef] [PubMed]

19. Naftali, T.; Mechulam, R.; Marii, A.; Gabay, G.; Stein, A.; Bronshtain, M.; Laish, I.; Benjaminov, F.; Konikoff, F.M. Lo-dose cannabidiol is safe but not effective in the treatment for chrohn's disease, a randomized controlled trial. Dig. Dis. Sci. 2017, 62, 1615-1620. [CrossRef]

20. Naftali, T.; Schleider, L.B.; Dotan, I.; Lansky, E.P.; Benjaminov, F.S.; Konikoff, F.M. Cannabis induces a clinical response in patients with crohn's disease: A prospective placebo-controlled study. Clin. Gastroenterol. Hepatol. 2013, 11, 1276-1280. [CrossRef]

21. Fiz, J.; Duran, M.; Capella, D.; Carbonell, J.; Farre, M. Cannabis use in patients with fibromyalgia: Effect on symptoms relief and health-related quality of life. PLoS ONE 2011, 6, e18440. [CrossRef]

22. Ware, M.A.; Fitzcharles, M.A.; Joseph, L.; Shir, Y. The effects of nabilone on sleep in fibromyalgia: Results of a randomized controlled trial. Anesth. Analg. 2010, 110, 604-610. [CrossRef]

23. Green, K. Marijuana smoking vs. cannabinoids for glaucoma therapy. Arch. Ophthalmol. 1998, 116, $1433-1437$. [CrossRef] [PubMed]

24. Flach, A.J. Delta-9-tetrahydrocannabinol (THC) in the treatment of end-stage open-angle glaucoma. Trans. Am. Ophthalmol. Soc. 2002, 100, 215-222. [PubMed]

25. Jay, W.M.; Green, K. Multiple-drop study of topically applied $1 \% \delta 9$-tetrahydrocannabinol in human eyes. Arch. Ophthalmol. 1983, 101, 591-593. [CrossRef] [PubMed]

26. Green, K.; Roth, M. Ocular effects of topical administration of delta 9-tetrahydrocannabinol in man. Arch. Ophthalmol. 1982, 100, 265-267. [CrossRef] [PubMed]

27. Sun, X.; Xu, C.S.; Chadha, N.; Chen, A.; Liu, J. Marijuana for Glaucoma: A Recipe for Disaster or Treatment? Yale J. Biol. Med. 2015, 88, 265-269. [PubMed] 
28. Abrams, D.I.; Hilton, J.F.; Leiser, R.J.; Shade, S.B.; Elbeik, T.A.; Aweeka, F.T.; Benowitz, N.L.; Bredt, B.M.; Kosel, B.; Aberg, J.A.; et al. Short-term effects of cannabinoids in patients with HIV-1 infection: A randomized, placebo-controlled clinical trial. Ann. Intern. Med. 2003, 139, 258-266. [CrossRef] [PubMed]

29. Timpone, J.G.; Wright, D.J.; Li, N.; Egorin, M.J.; Enama, M.E.; Mayers, J.; Galetto, G. Division of AIDS Treatment Research Initiative. The safety and pharmacokinetics of single-agent and combination therapy with megestrol acetate and dronabinol for the treatment of HIV wasting syndrome: The DATRI 004 Study Group. AIDS Res. Hum. Retroviruses 1997, 13, 305-315. [CrossRef]

30. Struwe, M.; Kaempfer, S.H.; Geiger, C.J.; Pavia, A.T.; Plasse, T.F.; Shepard, K.V.; Ries, K.; Evans, T.G. Effect of dronabinol on nutritional status in HIV infection. Ann. Pharmacother. 1993, 27, 827-831. [CrossRef]

31. Beal, J.E.; Olson, R.; Laubenstein, L.; Morales, J.O.; Bellman, P.; Yangco, B.; Lefkowitz, L.; Plasse, T.F.; Shepard, K.V. Dronabinol as a treatment for anorexia associated with weight loss in patients with AIDS. J. Pain Symptom Manag. 1995, 10, 89-97. [CrossRef]

32. Rhyne, D.N.; Anderson, S.L.; Gedde, M.; Borgelt, L.M. Effects of medical marijuana on migraine headache frequency in an adult population. Pharmacotherapy 2016, 36, 505-510. [CrossRef]

33. Corey-Blood, J.; Wolfson, T.; Gamst, A.; Jin, S.; Marcotte, T.D.; Bentley, H.; Gouaux, B. Cmoked cannabis for spasticity in multiple sclerosis: A randomized, placebo-controlled trial. Can. Med. Assoc. J. 2012, 184, 1143-1150. [CrossRef] [PubMed]

34. Zajicek, J.P.; Hobart, J.C.; Slade, A.; Barnes, D.; Mattison, P.G.; MUSEC Research Group. Multiple sclerosis and extract of cannabis: Results of the MUSEC trial. J. Neurol. Neurosurg. Psychiatry 2012, 83, 1125-1132. [CrossRef] [PubMed]

35. Novotna, A.; Mares, J.; Matcliffe, S.; Novakova, I.; Vachova, M.; Zapletalova, O.; Gasperini, C.; Pozzilli, C.; Cefaro, L.; Comi, G.; et al. A randomized, double-blind, placebo-controlled, parallel-group, enriched-design study of nabiximols (Sativex), as add-on therapy, in subjects with refractory spasticity caused by multiple sclerosis. Eur. J. Neurol. 2011, 18, 1122-1131. [CrossRef] [PubMed]

36. Notcutt, W.; Langford, R.; Davies, P.; Ratcliffe, S.; Potts, R. A placebo-controlled, parallel-group, randomized withdrawal study of subjects with symptoms of spasticity due to multiple sclerosis who are receiving long-term Sativex (nabiximols). Mult. Scler. 2012, 18, 219-228. [CrossRef] [PubMed]

37. Todaro, B. Cannabinoids in the treatment of chemotherapy-induced nausea and vomiting. J. Natl. Compr. Cancer Netw. 2012, 10, 487-492. [CrossRef]

38. Carroll, C.B.; Bain, P.G.; Teare, L.; Liu, X.; Joint, C.; Wroath, C.; Parkin, S.G.; Fox, P.; Wright, D.; Hobart, J.; et al. Cannabis for dyskinesia in Parkinson disease: A randomized double-blind crossover study. Neurology 2004, 63, 1245-1250. [CrossRef] [PubMed]

39. Koppel, B.S.; Brust, J.C.; Fife, T.; Bronstein, J.; Youssof, S.; Gronseth, G.; Gloss, D. Systematic review: Efficacy and safety of medical marijuana in selected neurologic disorders. Neurology 2014, 82, 1556-1563. [CrossRef]

40. Chagas, M.H.; Zuardi, A.W.; Tumas, V.; Pena-Pereira, M.A.; Sobreira, E.T.; Bergamaschi, M.M.; dos Santos, A.C.; Teixeira, A.L.; Hallak, J.E.; Crippa, J.A. Effects of cannabidiol in the treatment of patients with Parkinson's disease: An exploratory double-blind trial. J. Psychopharmacol. 2014, 28, 1088-1098. [CrossRef]

41. Yarnell, S. The use of medicinal marijuana for posttraumatic stress disorder: A review of the current literature. Prim Care Companion CNS Disord. 2015, 17. [CrossRef]

42. Jetly, R.; Heber, A.; Fraser, G.; Boisvert, D. The efficacy of nabilone, a synthetic cannabinoid, in the treatment of PTSD-associated nightmares: A preliminary randomized, double-blind, placebo-controlled cross-over design study. Psychoneuroendocrinology 2015, 51, 585-588. [CrossRef]

43. Roitman, P.; Mechoulam, R.; Cooper-Kazaz, R.; Shalev, A. Preliminary, open-label, pilot study of add-on oral delta-9-tetrahydrocannabinol in chronic post-traumatic stress disorder. Clin. Drug Investig. 2014, 34, 587-591. [CrossRef] [PubMed]

44. Wilkinson, S.T.; Radhakrishnan, R.; D'Souza, D.C. A systematic review of the evidence for medical marijuana in psychiatric indications. J. Clin. Psychiatry 2016, 77, 1050-1064. [CrossRef] [PubMed]

45. Devinsky, O.; Cross, J.H.; Laux, L.; Wright, S. Trial of cannabidiol for drug-resistant seizures in the Dravet syndrome. N. Engl. J. Med. 2017, 376, 2011-2020. [CrossRef] [PubMed] 
46. Thiele, E.A.; Marsh, E.D.; French, J.A.; Mazurkiewicz-Beldzinska, M.; Benbadis, S.R.; Joshi, C.; Lyons, P.D.; Taylor, A.; Roberts, C.; Sommerville, K.; et al. Cannabidiol in patients with seizures associated with Lennox-Gastaut syndrome (GWPCARE4): A randomized, double-blind, placebo-controlled phase 3 trial. Lancet 2018, 391, 1085-1096. [CrossRef]

47. Zuberi, S.; Devinsky, O.; Patel, A.; Cross, J.H.; Villaneuva, V.; Wirrell, E.C.; Roberts, C.; Checketts, D.; van Landingham, K. Cannabidiol (CBD) significantly decreases drop and total seizure frequency in Lennox-Gastaut syndrome (LGS): Results of a dose-ranging, multi-centre, randomised, double-blind, placebo-controlled trial (GWPCARE3). In Proceedings of the 32nd International Epilepsy Congress, Barcelona, Spain, 2-5 September 2017. in press.

48. Andrade, C. Cannabis and neuropsychiatry, 2: The longitudinal risk of psychosis as an adverse outcome. J. Clin. Psychiatry 2016, 77, e739-e741. [CrossRef] [PubMed]

49. Singh, A.; Saluja, S.; Kumar, A.; Agrawal, S.; Thind, M.; Nanda, S.; Shirani, J. Cardiovascular complications of marijuana and related substances: A review. Cardiol. Ther. 2017. [CrossRef] [PubMed]

50. Yamreudeewong, W.; Wong, H.K.; Brausch, L.M.; Pulley, K.R. Probably interaction between warfarin and marijuana smoking. Ann. Pharmacother. 2009, 43, 1347-1353. [CrossRef]

51. Kosel, B.W.; Aweeka, F.T.; Benowitz, N.L.; Shade, S.B.; Hilton, J.F.; Lizak, P.S.; Abrams, D.I. The effects of cannabinoids on the pharmacokinetics of indinavir and nelfinavir. AIDS 2002, 16, 543-550. [CrossRef]

52. Lucas, C.J.; Galettis, P.; Schneider, J. The pharmacokinetics and the pharmacodynamics of cannabinoids. Br. J. Clin. Pharmacol. 2018, 84, 2477-2482. [CrossRef]

53. Stout, S.M.; Ciminco, N.M. Exogenous cannabinoids as substrates, inhibitors, and inducers of human drug metabolizing enzymes: A systematic review. Drug Metab. Rev. 2014, 46, 86-95. [CrossRef]

54. Vandrey, R.; Raber, J.C.; Raber, M.E.; Douglass, B.; Miller, C.; Bonn-Miller, M.O. Cannabinoid dose and label accuracy in edible medical cannabis products. JAMA 2015, 313, 2491-2493. [CrossRef] [PubMed]

(c) 2018 by the author. Licensee MDPI, Basel, Switzerland. This article is an open access article distributed under the terms and conditions of the Creative Commons Attribution (CC BY) license (http:/ / creativecommons.org/licenses/by/4.0/). 